\title{
DINAMIKA SERTA PERKEMBANGAN DEMOKRASI DI INDONESIA
}

\author{
Kanti Wahyuning Putri \\ Institut Ilmu Kesehatan Strada Indonesia \\ kantiwahyuningputri@gmail.com
}

\begin{abstract}
ABSTRAK
Perjalanan dan perkembangan demokrasi di Indonesia selama ini telah mengalami beberapa fase. Dimana dalam setiap periode terdapat dinamika dan problematika pencapaian demokrasi di Indonesia. Perubahan pola demokrasi terjadi mulai dari demokrasi terpimpin, demokrasi parlementer sampai pada demokrasi di era reformasi. Penulisan artikel ini bertujuan untuk mengetahui dan mendeskripsikan perjalanan dan perkembangan demokrasi di Indonesia. Adapun penulisan artikel ini menggunakan metode kepustakaan atau studi literatur yaitu dengan menelaah dan memahami isi buku-buku, dokumen, atau sumber ilmiah lainnya yang relevan dan mendukung untuk mendeskripsikan perjalanan dan perkembangan demokrasi di Indonesia. Artikel ini nantinya akan membahas perjalanan dan perkembangan serta dinamika demokrasi di Indonesia.
\end{abstract}

\section{Latar Belakang}

Demokrasi berasal dari Yunani Kuno yang dinyatakan di Athena kuno pada abad ke-5 Sebelum Masehi. Negara-Kota Athena tersebut dipercaya sebagai awalan dari suatu sistem yang berkaitan dengan hukum demokrasi modern. Namun, maknanya dari itu berubah seiring dengan waktu dan pengertian kini sudah berubah secara lambat sejak abad ke-18, bersamaan dengan perkembangan komposisi demokrasi (Nihaya, 2016: 15). Demokrasi dapat didefinisikan sebagai pemerintahan rakyat, atau yang sering kita dengar dengan pemerintahan dari rakyat, oleh rakyat dan untuk rakyat. Konsepsi demokrasi menjadi suatu poin inti tersendiri dalam bidang ilmu politik. Hal ini wajar, karena demokrasi sekarang ini disebut sebagai indeks perkembangan politik suatu Negara (Nihaya, 2016: 15). 
Demokrasi menduduki posisi penting dalam hubungan pembagian kekuasaan dalam suatu negara yang berdasarkan pada konsep trias politica dengan kekuasaan negara yang didapat dari rakyat juga harus dipakai guna kesejahteraan dan kemakmuran rakyat (Nihaya, 2016: 15). Konsep trias politica teramat penting untuk diperlibatkan saat fakta sejarah merekam kekuasaan pemerintah yang ternyata ketidakmampuan kekuasaan pemerintah dalam menjadikan masyarakat yang adil dan beradab, kadang sering juga kekuasaan mutlak pemerintah memunculkan penyimpangan atau terjadinya pelanggaran pada hak-hak rakyat. (Nihaya, 2016: 16). Adapun juga perihal tentang kekuasaan yang berlebih di lembaga negara yang lain, seperti kekuasaan berlebih dari lembaga negara legislatif yang menetapkan sendiri anggaran untuk gaji dan tunjangan anggotanya tanpa memperhatikan dan mempedulikan aspirasi rakyat (Nihaya, M, 2016: 16). Jadi poinnya, tiap lembaga negara tidak hanya harus akuntabel, tapi juga harus ada mekanisme formal yang mewujudkan jiwa akuntabilitas dari setiap lembaga negara dan mekanisme itu dapat mampu membatasi kekuasaan lembaga negara tersebut (Nihaya, M, 2016: 16).

\section{Kata Kunci : Demokrasi}

\section{Rumusan/Masalah}

Bagaimana dinamika serta perkembangan demokrasi di Indoesiasia?

\section{Tinjauan Pustaka}

Perkembangan dan perjalanan demokrasi di Indonesia berdasarkan waktu terbagi menjadi empat fase, yakni:

1. Demokrasi Parlementer Fase 1945-1959 Demokrasi di fase ini sering kita dengar dengan sebutan Demokrasi Parlementer. Demokrasi ini mulai berlaku pada satu bulan pasca kemerdekaan di proklamasikan dan juga mulai diperkuat dalam UUD 1945 dan 1950, namun ternyata sistem demokrasi ini kurang serasi bagi negara 
Indonesia, walaupun bisa berjalan dengan baik di beberapa negara lain (Purnamawati, 2020: 255).

2. Demokrasi Terpimpin Fase 1959-1965 Dalam sistem demokrasi pada fase ini, ciri menonjolnya adalah lebih banyaknya peran presiden dan terbatasnya peran partai politik. Dalam praktik pemerintahan, pada fase ini sudah banyak melakukan penyimpangan terhadap demokrasi. Dekrit Presiden 5 Juli bisa dianggap sebagai suatu upaya guna mencari solusi dari kemacetan politik yang terjadi dalam sidang konstituante yang merupakan satu bentuk penyimpangan praktik demokrasi (Purnamawati, 2020: 256).

3. Demokrasi Pancasila Fase 1965-1998 Fase pemerintahan ini muncul sesudah berakhirnya G30SPKI. Landasan formil fase ini ialah Pancasila, UUD 1945, dan ketetapan MPRS. Semangat motivasi yang menjadi dasar munculnya atau lahirnya fase ini yakni keinginan guna memperbaiki atau mengembalikan dan memurnikan penyelenggaraan pemerintahan yang didasarkan Pancasila dan UUD 1945 secara murni (Purnamawati, 2020: 257).

4. Demokrasi di Era Reformasi Pelaksanaan demokrasi di era reformasi pada tahun 1998 sampai sekarang ditandai dengan lengsernya presiden terdahulu, Soeharto yang menjabat sebagai presiden sekitar 32 tahun. Demokrasi Indonesia era reformasi memosisikan fondasi yang kuat bagi penyelenggaraan demokrasi Indonesia di masa selanjutnya. Ditemukan berbagai indeks penyelenggaraan demokrasi di Indonesia, yaitu diberikannya kebebasan pers sebagai ruang terbuka untuk ikut terlibat dalam urusan kenegaraan dan berlakunya sistem multipartai, diberlakukannya ini nampak pada Pemilu tahun 1999. Di era ini rakyat berpeluang untuk bersatu dan berkumpul sesuai paham ideologi dan aspirasi politiknya (Purnamawati, 2020: 257-258).

\section{Pembahasan}

\section{PERKEMBANGAN DEMOKRASI DI INDONESIA}

Dalam sejarah teori demokrasi, terbagi menjadi dua fakta historis yang penting (dalam Buku berjudul Ilmu Negara). Pertama, sebagian dan hampir semua orang 
di masa sekarang menganggap dirinya sebagai demokrat. Namun, yang disebutkan atan katakan dan dilakukan atau perbuat oleh rezim yang satu dengan yang lainnya sering berbeda. Kemudian yang kedua, banyaknya negara yang menganut ide demokrasi, lembaga politiknya menyatakan adanya kerawanan dan kerapuhan tatanan demokrasi (Purnamawati, 2020: 254). Perkembangan demokrasi di Indonesia terdapat dua tahap yakni tahapan sebelum atau pra kemerdekaan dan tahapan sesudah atau pasca kemerdekaan. Perkembangan demokrasi di Indonesia sesudah kemerdekaan mengalami ketidakstabilan dari masa kemerdekaan sampai saat sekarang ini, permasalahan inti yang dihadapi adalah bagaimana demokrasi itu membentuk dirinya dalam berbagai sisi negatif kehidupan berbangsa dan bernegara. Sebagai tatanan kehidupan, pokok tatanan kehidupan demokratis secara empiris terhubung dengan permasalahan pada korelasi antar pemerintah dengan rakyat, atau sebaliknya korelasi antar rakyat dengan pemerintah dalam posisi seimbang dan saling melaksanakan pengawasan satu sama lain. (Purnamawati, 2020: 254-255).

\section{Kesimpulan}

Demokrasi di Indonesia berkembang selaras dengan pergejolakan politik yang terjadi pasca kemerdekaan. Perubahan pola demokrasi terjadi mulai dari demokrasi terpimpin, parlementer sampai pada era reformasi. Namun pada dasarnya, peran pemerintahan dalam melaksanakan demokrasi masih sangat lebih banyak, sebab dalam UUD 1945 serta perubahannya, masih terlihat kekuasaan pemerintahan lebih banyak dibanding kekuasaan lainnya (Irawan, 2016: 63). Indonesia dalam pelaksanaan demokrasi mengalami beberapa fase, hingga sekarang ini dikenal dengan era reformasi. Negara demokrasi, tentu membetulkan adanya partai politik sebagai sendi dari demokrasi atau penyelenggaraan kedaulatan rakyat itu. Hal demikian pada dasarnya pada penyelenggaraan demokrasi secara tidak langsung atau dilakukan melalui pemilu dalam rangka menjabati posisi kepemimpinan suatu negara yang adanya partai politik sebagai anggota pemilu. Partai politik pada dasarmya mempunyai posisi dan peran yang 
terpusat dan penting dalam tiap sistem demokrasi sebab melibatkan peran yang penting sebagai penyalur antara pemerintahan negara dengan rakyatnya.

\section{Daftar Pustaka}

Siyoto, S., \& Sodik, M. A. (2015). Dasar metodologi penelitian. Literasi Media Publishing.

Sodik, M. A., Suprapto, S. I., \& Pangesti, D. (2013). Faktor-Faktor Yang Berhubungan Dengan

Pelaksanaan Pelayanan Prima Pegawai Di Rsui Orpeha Tulungagung. STRADA Jurnal Ilmiah Kesehatan, 2(1), 24-32.

Sodik, M. A., \& Nzilibili, S. M. M. (2017). The Role Of Health Promotion And Family Support

With Attitude Of Couples Childbearing Age In Following Family Planning Program In Health.

Journal of Global Research in Public Health, 2(2), 82-89.

Setyani, A. T., \& Sodik, M. A. (2018). Pengaruh Merokok Bagi Remaja Terhadap Perilaku dan Pergaulan Sehari-hari.

Attoriq, S., \& Sodik, M. A. (2018). Pencegahan Dan Pengendalian Infeksi Terkait Pelayanan Kesehatan Di Lahan Praktik.

Rahman, M. (2021). DINAMIKA SERTA PERKEMBANGAN DEMOKRASI DI INDONESIA

Irawan, B. B. (2016). Perkembangan Demokrasi di Negara Indonesia. Jurnal Ilmiah Hukum dan Dinamika Masyarakat, 5(1).

Purnamawati, E. (2020). Perjalanan Demokrasi di Indonesia. Solusi, 18(2), 251-264

Nihaya, M. (2016). Demokrasi dan Problematikanya di Indonesia. Sulesana: Jurnal Wawasan

Keislaman, 10(2), 35-49

Purnaweni, H. (2004). Demokrasi Indonesia: Dari Masa ke Masa. Jurnal Administrasi Publik Vol 3 No. 2, UNPAR, 2004., 3.

PUTRI, K. W. (2021). Menanamkan Nilai Persatuan Dan Kesatuan Melalui Pembelajaran Sejarah.

Putri, K. W. (2021). Memahami Kesehatan Sebagai Hak Asasi Manusia. 
